\title{
Accumulation and distribution of organophosphate flame retardants (PFRs) and their di-alkyl phosphates (DAPs) metabolites in different freshwater fish from locations around Beijing, China ${ }^{\text {iz }}$
}

\author{
Rui Hou ${ }^{\text {a, b, c, Cao Liu }}{ }^{\text {d }}$, Xiaozhong Gao ${ }^{\text {a, b, c }}$, Yiping Xu ${ }^{\text {a, * }}$, Jinmiao Zha ${ }^{\text {a }}$, Zijian Wang ${ }^{\text {b }}$ \\ ${ }^{a}$ Key Laboratory of Drinking Water Science and Technology, Research Center for Eco-Environmental Sciences, Chinese Academy of Sciences, Beijing 100085, \\ China \\ b State Key Laboratory of Environmental Aquatic Chemistry, Research Center for Eco-Environmental Sciences, Chinese Academy of Sciences, Beijing 100085, \\ China \\ ${ }^{\mathrm{c}}$ University of Chinese Academy of Sciences, Beijing 100049, China \\ ${ }^{\mathrm{d}}$ Beijing Water Sciences Technology Institute, Beijing 100085, China
}

\section{A R T I C L E I N F O}

\section{Article history:}

Received 5 December 2016

Received in revised form

31 May 2017

Accepted 28 June 2017

Available online 6 July 2017

\section{Keywords:}

Organophosphate flame retardants (PFRs)

Metabolites

Di-alkyl phosphates (DAPs)

Freshwater fish

Tissue distribution

\begin{abstract}
A B S T R A C T
Organophosphate flame retardants (PFRs) can be rapidly metabolized in the body, and recent studies have shown that the di-alkyl phosphates (DAPs) are important metabolites. The accumulation and distribution of 8 PFRs and their 4 DAPs metabolites were first investigated in whole-body samples and various tissues of three freshwater fish species (topmouth gudgeon, crucian carp and loach) with different feeding habits from locations around Beijing, China. Concentrations of $\Sigma$ PFRs in whole-body samples across all sampling locations ranged from 264.7 to $1973 \mathrm{ng} \mathrm{g}^{-1}$ lipid weight (lw), while all the paired DAP metabolites were detected in the total range from 35.3 to $510 \mathrm{ng} \mathrm{g}^{-1} \mathrm{lw}$. The calculated $\log$ bioconcentration factors (BCFs) of PFRs in whole fish were correlated with their $\log K_{\mathrm{OW}}(P<0.05)$. The metabolite/parent ratios (MPRs) of $\Sigma$ DAPs were calculated and ranged from 0.10 to 1.12 in whole-fish of all species. The MPRs of BBOEP/TBOEP were the highest. With respect to their distribution in different tissues, both the parent PFRs and metabolites were found at relatively higher levels in the liver than in other tissues (muscle, intestine, kidney and ovary), which was markedly different from those observed in avian species in previous studies. The accumulation of PFRs and DAPs in various tissues was not significantly correlated with the lipid content. The highest PFRs level in the liver may be related to the active hepatic accumulation processes. Meanwhile, the MPRs for all 4 pairs were the highest in the kidney relative to the other tissues. To the best of our knowledge, this is first study of DAPs in wild animals, and our study may improve the understanding of the accumulation and metabolism of PFRs in the body.
\end{abstract}

(c) 2017 Elsevier Ltd. All rights reserved.

\section{Introduction}

Organophosphate flame retardants, with a standardized abbreviation of PFRs, are widely used as flame retardants and plasticizers in plastics, rubber, upholstery, paint, and textiles, etc. (Bergman et al., 2012; Van der Veen and de Boer, 2012). In recent years, the production and use of PFRs have increased due to the phase-out of polybrominated diphenyl ethers (PBDEs). PFRs are

\footnotetext{
This paper has been recommended for acceptance by Prof. von Hippel Frank A.

* Corresponding author.

E-mail address: ypxu@rcees.ac.cn (Y. Xu).
}

typically applied to end products through physical addition, resulting in the loss of PFRs through volatilization, abrasion and leaching during their lifetime (Sundkvist et al., 2010). As a result, PFRs are ubiquitous in the environmental matrix of indoor dust (Cequier et al., 2014a; Staaf and Ostman, 2005), atmosphere (Lai et al., 2015; Shoeib et al., 2014), surface water (Andresen et al., 2004; Cristale et al., 2013; Wang et al., 2015), sediment (Cao et al., 2012; Chung and Ding, 2009; Giulivo et al., 2017) and soil (Mihajlović et al., 2011). Tris(2-chloroethyl) phosphate (TCEP), tris(2-butoxyethyl) phosphate (TBOEP), tris(2-chloroisopropyl) phosphate (TCIPP), trisphenyl phosphate (TPHP), tris-n-butyl phosphate (TNBP) and tris(1,3-dichloro-2-propyl) phosphate (TDCIPP) are the PFRs of most concern due to their ubiquitous 
presence in the environment (Wei et al., 2015).

Several toxicological studies have shown that exposure to PFRs, such as TPHP, TNBP, TDCIPP, TCEP, and TBOEP, etc., can potentially cause adverse reproductive effects, endocrine disruptive effects and systemic effects in fish, birds, rodents and humans (Wei et al., 2015). Chlorinated PFRs such as TCEP, TCIPP and TDCIPP were also shown to be neurotoxic and carcinogenic (Van der Veen and de Boer, 2012; WHO, 1998, 2000). Consequently, chlorinated PFRs such as TDCIPP and TCEP were prohibited in child care products in multiple states in the USA such as Massachusetts, Maryland, New York and Vermont, etc., and especially banned in both children's products and residential upholstered furniture in Washington D.C. and Washington state (State of Washington, 2016; The District of Columbia, 2016).

Relatively few studies have investigated PFRs in biota, particularly in fish and other wildlife. Higher levels of PFRs were found in the freshwater fish of Swedish lakes (>1000 $\mathrm{ng} \mathrm{g}^{-1}$ lipid weight) and in river fish from Spain (up to $2423 \mathrm{ng} \mathrm{g}^{-1}$ lipid weight) (Santín et al., 2016; Sundkvist et al., 2010). Kim et al. (2011) found that tris(2-ethylhexyl) phosphate (TEHP), triethyl phosphate (TEP) and TNBP were the main contributors to the total PFR levels in fish from Manila Bay, Philippines. McGoldrick et al. (2014) investigated PFR concentrations in predatory freshwater fish, in which TCEP were the most frequently quantified PFRs and were found to exist in concentrations ranging from $<0.07$ to $9.8 \mathrm{ng} \mathrm{g}^{-1}$ wet weight (ww). Additionally, PFRs were also detected in fish from three river basins of Greece, Italy and Slovenia, with total concentrations ranging from 14.4 to $650 \mathrm{ng} \mathrm{g}^{-1}$ lipid weight (lw) (Giulivo et al., 2017). A recent investigation into the distribution of PFRs in the bodies of Great Lakes herring gulls showed that the concentrations and proportions were distinct for different tissues (Greaves and Letcher, 2014). The fat, egg and muscle contained relatively higher $\Sigma$ PFR concentrations, while no PFRs were detected in the liver, blood plasma or brain of the herring gulls. However, to the best of our knowledge, there have been no studies on the tissue distribution of PFRs in any fish species.

PFRs can be rapidly metabolized in the body (Lynn et al., 1981; Nomeir et al., 1981; Sasaki et al., 1984; Suzuki et al., 1984). Recently, a limited number of in vitro studies have been conducted to examine the metabolic pathways of PFRs, including TDCIPP, TCIPP, TCEP, TBOEP, TPHP, 2-ethylhexyl diphenyl phosphate (EHDPHP) and resorcinol diphenyl phosphate (RDP) (BallesterosGómez et al., 2015a, 2015b; Su et al., 2015; Van den Eede et al., 2015a; Van den Eede et al., 2013a). The general metabolic pathway of PFRs includes $O$-dealkylation, hydroxylation, carboxylation, oxidative dehalogenation and phase II conjugation, resulting in a wide array of metabolites (Hou et al., 2016). Di-alkyl phosphates (DAPs) from the $O$-dealkylation metabolism, such as bis(1,3-dichloropropyl) phosphate (BDCIPP), bis(1-chloro-2propyl) phosphate (BCIPP), bis(2-chloroethyl) phosphate (BCEP), bis(2-butoxyethyl) phosphate (BBOEP), di-n-butyl phosphate (DNBP), diphenyl phosphate (DPHP), and diethylhexyl phosphate (DEHP), were deemed important biomarkers in recent human biomonitoring studies (Butt et al., 2014; Cequier et al., 2014b, 2015; Chu et al., 2011; Cooper et al., 2011; Dodson et al., 2014; Meeker et al., 2013b; Reemtsma et al., 2011; Van den Eede et al., 2015b; Van den Eede et al., 2013b).

Although some studies have investigated PFRs in wildlife, it should be noted that the PFRs accumulated in animal bodies in these studies were probably post-metabolic residues (or unmetabolized PFRs) (Greaves and Letcher, 2014). Since DAPs are thought to be the major metabolites of many PFRs, their concentrations can not only provide valuable information for understanding the accumulation of PFRs but also give insight into the metabolism and toxicology of PFRs in the body (Greaves and
Letcher, 2014). Recently, a finite number of published works have also focused on the toxic effects of DAPs, especially for DPHP. An in vitro study confirmed that DPHP could alter more transcripts related to lipid metabolism and cholesterol-related genes in chicken embryonic liver cells than its parent compound TPHP (Su et al., 2014). In addition, urinary DPHP was found to have a significant association with decreased sperm concentrations in males and increased total thyroxine levels in females (Meeker et al., 2013a; Preston et al., 2017). However, there is very limited information available regarding DAPs in environmental biotic samples. Therefore, the primary goal of this study was to conduct a pilot field investigation of the metabolism of PFRs and develop a tissue distribution profile of DAPs and PFRs in dominant freshwater fish collected from bodies of water in Beijing, China.

\section{Materials and methods}

\subsection{Chemicals and standards}

PFR standards for TDCIPP, TCEP, TCIPP, TBOEP, TNBP, TPHP, TEHP and EHDPHP were purchased from Accustandard, Inc. (New Haven, CT, USA). The DAPs of BBOEP, DPHP, DNBP and DEHP were purchased from Toronto Research Chemicals (Toronto, ON, Canada). The internal standards for PFRs (TDCIPP-d15 and TPHP-d15) and internal standards for DAPs (BBOEP-d4) were also purchased from Toronto Research Chemicals (Toronto, ON, Canada). Two internal standards were chosen based on the similarity of their chemical structure to that of PFRs: TDCIPP-d15 was used as an internal standard for TCEP, TCIPP, TDCIPP, TNBP and TBOEP, while TPHP-d15 was used for TPHP, TEHP and EHDPHP. In the analysis of DAPs, BBOEP-d4 was chosen as an internal standard for BBOEP, DNBP, DPHP and DEHP. All standards had a chemical purity ranging between $95 \%$ and $100 \%$.

\subsection{Sample collection}

Fish were collected from 9 locations in urban surface water in Beijing during December 2015 (Fig. 1). These bodies of water all belong to the Beiyun river system, which covers the most densely populated, industrial and urbanized districts in Beijing. The three most common freshwater fish present different feeding habits in this area were collected, i.e., topmouth gudgeon (Pseudorasbora parva), crucian carp (Carassius auratus) and loach (Misgurnus anguillicaudatus) (Kang et al., 2014), and the number, species, body length, body weight and lipid content of the fish are listed in Table S1. Samples in this study consisted of whole-body fish and tissue samples (including muscle, liver, intestine, kidney and ovary). Whole-body fish samples were collected at all locations. Tissue samples were only collected from crucian carp (in Nanhucheng river and Tonghui River) and loach (in Tonghui river, Macao river and Fenggangjian river). All samples were freeze-dried for at least $72 \mathrm{~h}$ and then homogenized. After processing, the homogenized fish samples were stored at $-80{ }^{\circ} \mathrm{C}$ until analysis. In each sampling points, surface water and sediment samples were also collected and stored at $-80{ }^{\circ} \mathrm{C}$. Details regarding the analysis of PFRs in water and sediment are provided in Supplementary Information II.

\subsection{Chemical analysis of PFRs}

TDCIPP, TCIPP, TCEP, TBOEP, TNBP, TEHP, TPHP and EHDPHP were selected as target compounds in our study. The analysis of the 8 PFRs followed the procedures described previously with slight modifications (Chen et al., 2012). Each sample (0.5 g homogenate) was spiked with $10 \mathrm{ng}$ of TDCIPP-d15 and TPHP-d15 and then 


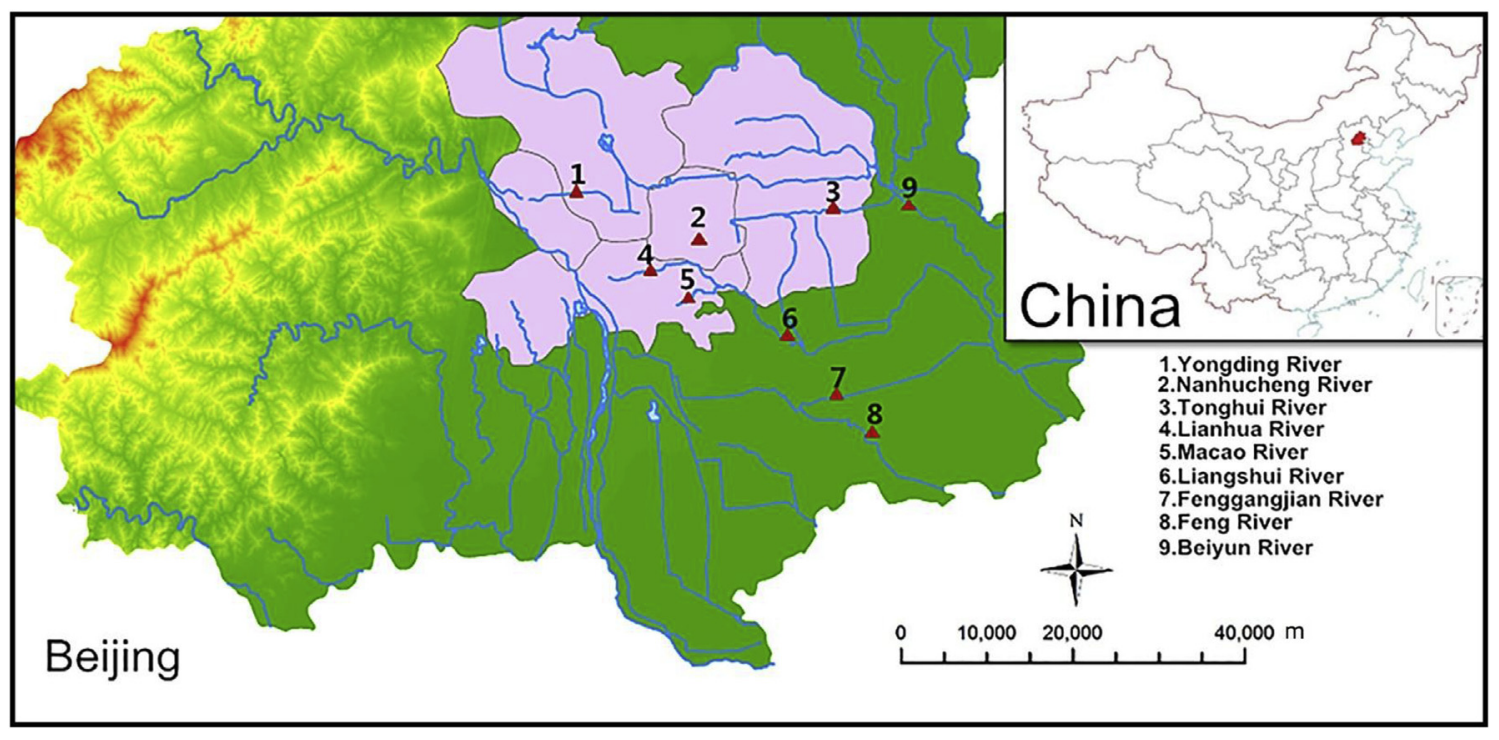

Fig. 1. Map of sampling locations for this study.

extracted with a dichloromethane/n-hexane (DCM/hexane) mixture $(1: 4, v / v)$ using an accelerated solvent extractor (Dionex ASE 350, USA). The lipid content was determined gravimetrically using an aliquot of the extract, while the rest of the extract was further purified using an SPE- $\mathrm{NH}_{2}$ cartridge $(1 \mathrm{~g}, 6 \mathrm{ml}$, Bond Elut $\mathrm{NH}_{2}$ ). After rising the cartridge with $5 \mathrm{ml}$ of $20: 80 \mathrm{DCM} /$ hexane, PFRs were eluted using $3 \mathrm{ml}$ of 20:80 DCM/hexane, followed by $8 \mathrm{ml}$ of DCM, and finally $4 \mathrm{ml}$ of $90: 10 \mathrm{DCM} /$ methanol. The eluent was reduced to near dryness under nitrogen, then reconstituted in $0.5 \mathrm{ml}$ of methanol and transferred to a glass vial for analysis.

Analysis of the PFRs was performed on a Waters Acquity UPLC coupled to a Waters Quattro Premier XE Mass Spectrometer (UPLCMS/MS) under positive electrospray ionization mode (ESI+). The column used was a Waters BEH C18 column $(100 \mathrm{~mm} \times 2.1 \mathrm{~mm}$, $3.5 \mu \mathrm{m}$ particle size). The detailed information, including all multiple reaction monitoring (MRM) data, can be found in Table S2.

\subsection{Chemical analysis for DAPs}

A previously published method was adopted for analysis of 4 DAPs (BBOEP, DNBP, DEHP and DPHP) in biological samples (Su et al., 2014), with some minor modifications. Approximately $0.5 \mathrm{~g}$ of homogenate was ground with $1 \mathrm{~g}$ of diatomaceous earth and spiked with $20 \mathrm{ng}$ of the deuterated DAP internal standard (BBOEPd4). The sample was also subjected to ASE (Dionex ASE 350, USA) with acetone at $100{ }^{\circ} \mathrm{C}$ and 1500 psi for 3 cycles. Sample cleanup was performed with the previous SPE- $\mathrm{NH}_{2}$ cartridge $(1 \mathrm{~g}, 6 \mathrm{ml}$, Bond Elut $\mathrm{NH}_{2}$ ), but the procedures were different. The analyte was loaded in the cartridge, and then the cartridge was washed with $5 \mathrm{ml}$ of acetone. The analyte was eluted into a glass tube with $2 \mathrm{ml}$ of methanol, then by $5 \mathrm{ml}$ of $3 \% \mathrm{v} / \mathrm{v} \mathrm{NH} \mathrm{NH}_{4} \mathrm{OH}$ in methanol. The eluate was evaporated to near dryness and reconstituted in $0.5 \mathrm{ml}$ of methanol.

The quantification of DAPs was also performed on the UPLC-MS/ MS with the Waters BEH C18 column $(100 \mathrm{~mm} \times 2.1 \mathrm{~mm}, 3.5 \mu \mathrm{m}$ particle size). The mobile phases were water (A) and methanol (B), both containing $2 \mathrm{mM}$ triethylamine (TEA) and $2 \mathrm{mM}$ acetic acid. The mobile phase flow rate was $0.3 \mathrm{ml} \mathrm{min}^{-1}$ and the gradient was as follows: $0-1$ min with $5 \%$ B, 1.5 min with $15 \%$ B, 4 min with $40 \%$ B, 6-9 min with $95 \% \mathrm{~B}$, and $9.1-10$ min with $5 \% \mathrm{~B}$. The injection volume was $10 \mu \mathrm{l}$. An MRM method was used with the source operated in negative electrospray ionization (ESI-) mode. The capillary voltage was $3500 \mathrm{~V}$, the source and desolvation temperatures were 110 and $650{ }^{\circ} \mathrm{C}$, respectively, and the cone gas and desolvation gas were set to 50 and $1100 \mathrm{~L} \mathrm{~h}^{-1}$, respectively. MRM transitions were optimized for each analyte and the corresponding internal standards. The compound-dependent operation parameters and target compound retention times are shown in Table S2.

\subsection{Quality control}

Lipid contents were determined by a gravimetric technique on sub-samples taken from the original extracts. The limits of quantification (MLOQ) for the method were defined as the minimum amount of analyte needed to produce a peak with a calculated signal to noise ratio of 10 . Method blanks consisted of triplicate samples of internal standard-spiked diatomaceous earth carried through the entire extraction, concentration and determination procedure with each batch of samples $(n=10)$ for both PFRs and DAPs. The mean method blank values were subtracted from the values of the samples. Quality controls (100 $\mathrm{ng} \mathrm{ml}^{-1}$ mixed standards, $n>6$ ) were also checked every batch of injections to ensure analysis stability (i.e. Inter-day RSD\%) (Table S3). Recovery experiments were performed by 6 replicates of $500 \mathrm{mg}$-spiked diatomaceous earth with PFR and DAP standards (100 ng). The recoveries of PFRs during the analytical procedure ranged between $55.3 \%$ and $102.1 \%$, while recoveries of DAPs were measured from $52.8 \%$ to $96.8 \%$. Matrix effects were also evaluated in the samples (500 mg fish homogenate), the matrix spike (100 ng standards in $500 \mathrm{mg}$ fish homogenate) and the blank spike (100 $\mathrm{ng} \mathrm{ml}^{-1}$ standards in methanol), with values ranging from $60 \%$ to $120 \%$ for PFRs and from $76 \%$ to $116 \%$ for DAPs. Our results demonstrate that the method is accurate, precise and selective in the analysis of PFRs and DAPs in fish samples. The method blanks, MLOQs, recoveries and matrix effects for the determination of the target compounds are listed at Table S3.

\subsection{Data analysis}

For statistical analysis, IMB SPSS Statics 21 (SPSS Inc., 2012) was used. Pearson correlation was performed to investigate the correlation between the concentration of PFRs and lipid content in 
tissues and for the correlation between $\log K_{\mathrm{OW}}$ and $\log \mathrm{BCF}$ of the target compounds. One-way ANOVA was also used for the comparison of differences in $\Sigma$ PFRs and $\Sigma$ DAPs among species, and twoway ANOVA was utilized to analyze the difference in PFR composition patterns and BCFs among species. The test results are considered statistically significant when the $P$ value is less than 0.05 .

\section{Results and discussion}

\subsection{Levels and tissue distribution of PFRs in fish}

\subsubsection{Whole-body concentrations of PFRs}

Lipid normalized concentrations of PFRs in whole-body fish samples are shown in Fig. 2. Of the 8 PFR congeners analyzed in this study, TNBP, TCEP and TCIPP were found in all fish samples (100\%), whereas TEHP and TPHP were found in $>90 \%$ of the fish samples, and TBOEP, EHDPHP and TDCIPP were found in only $78 \%, 42 \%$ and $35 \%$ of the samples, respectively. The mean value for $\Sigma$ PFRs at the 9 sites was $822 \mathrm{ng} \mathrm{g}^{-1} \mathrm{lw}$, from values ranging between 265 and $1973 \mathrm{ng} \mathrm{g}^{-1} \mathrm{lw}$, indicating the ubiquitous and extensive distribution of PFRs in fish from our research rivers. This is probably because the sampling rivers are mainly located in the downstream of urban and outer suburb areas, and their water supplement is mostly from renewable water mixed with sewage water (Jing et al., 2013). With regard to $\Sigma$ PFR concentrations among species, no obvious difference could be found in our study $(P=0.76)$. The similar PFRs concentrations for different species may be possibly due to the low river depth $(<1 \mathrm{~m})$, which provides an identical living environment for all species. Because the analyzed PFR congeners may be different, we compared the concentration of chlorinated PFRs (sum of TDCIPP, TCEP and TCIPP, which are the most persistent and commonly analyzed congeners), as well as the $\Sigma$ PFRs, with those reported worldwide for freshwater and marine fish (Table 1). The levels of chlorinated PFRs and $\Sigma$ PFRs in the present study were close to the concentrations in freshwater fish from the Pearl River Delta region in southern China (Ma et al., 2013). The moderate PFR residues in fish of the present study indicated a non-negligible threat of PFRs to aquatic organisms in our investigated rivers of Beijing.

Regarding the contribution (the proportion to the $\Sigma$ PFRs) of the PFR congeners in fish samples, the studied compounds in decreasing order were TNBP $(30 \%$ of the $\Sigma$ PFRs) $>$ TCEP (23\%) > TCIPP $(17 \%)>\operatorname{TEHP}(14 \%)>\operatorname{TPHP}(7 \%)>$ EHDPHP (3.5\%) > TDCIPP (3.3\%) > TBOEP (2.7\%). The most concentrated PFR congener in the fish samples was TNBP, which ranged from 64.4 to $449 \mathrm{ng} \mathrm{g}^{-1} \mathrm{lw}$ in whole-body samples, followed by TCEP and TCIPP, which ranged from 34.9 to $670 \mathrm{ng} \mathrm{g}^{-1} \mathrm{lw}$ and $51-401 \mathrm{ng} \mathrm{g}^{-1} \mathrm{lw}$ in whole-body samples, respectively. Interestingly, TNBP, TCEP and TCIPP have relatively moderate or low $\log K_{\mathrm{OW}}$ values of $4.00,1.63$ and 2.89, respectively (Van der Veen and de Boer, 2012). The accumulation of TNBP, TCEP and TCIPP in fish can be attributed to their higher environmental contamination levels as the production volume and application of these PFRs increased over time. TNBP, TCEP and TCIPP were the most produced and used PFRs around the world (Van der Veen and de Boer, 2012) and the most abundant PFRs detected in the surface water and sediment of China (Cao et al., 2012; Hu et al., 2014; Tan et al., 2016; Wang et al., 2015). Higher concentrations of TNBP, TCEP and TCIPP were also found in fish collected from bodies of water in the Pearl River Delta region in southern China at higher concentrations (43.9-2946 ng $\mathrm{g}^{-1} \mathrm{lw}$, 82.7-4692 $\mathrm{ng} \mathrm{g}^{-1} \mathrm{lw}$ and 62.7-883 $\mathrm{ng} \mathrm{g}^{-1} \mathrm{lw}$, respectively) (Ma et al., 2013). Kim et al. (2011) also reported comparable concentrations of TNBP (nd-590 $\mathrm{ng} \mathrm{g}^{-1} \mathrm{lw}$ ) in fish collected from Manila Bay, Philippines. Therefore, the considerable presence of these compounds in the environment might be the cause of their relatively high concentrations in fish in the present study compared with other PFRs, despite their lower log $K_{\text {Ow }}$ values. Indeed, in the rivers we investigated, TNBP was one of the congeners detected in the highest concentrations in the water and sediment from the rivers, ranging from 25.7 to $233 \mathrm{ng} \mathrm{L}^{-1}$ and nd-11 $\mathrm{ng} \mathrm{g}^{-1} \mathrm{dw}$ (dry weight), respectively (Table S4). In addition, the concentrations of

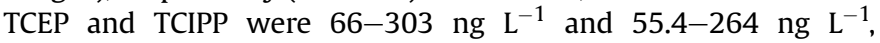
respectively in water from the survey areas, and were 35-200 $\mathrm{ng} \mathrm{g}^{-1} \mathrm{dw}$ and 50-277 $\mathrm{ng} \mathrm{g}^{-1} \mathrm{dw}$, respectively in sediment from the survey areas (Table S4), making them the most dominant PFR components both in water and sediment from the rivers. As far as the PFRs found at lower concentrations in fish (TBOEP, EHDPHP and TDCIPP), we also found relatively low levels of these compounds in water and sediments, with mean concentrations of less than $25.9 \mathrm{ng} \mathrm{L}^{-1}$ and $10.4 \mathrm{ng} \mathrm{g}^{-1} \mathrm{dw}$ (Table S4), respectively.

The bioconcentration factors (BCFs) of the 8 PFR congeners in whole-body fish were calculated by dividing the concentrations in

\section{Mean PFRs (ng/g lw) in whole-body}

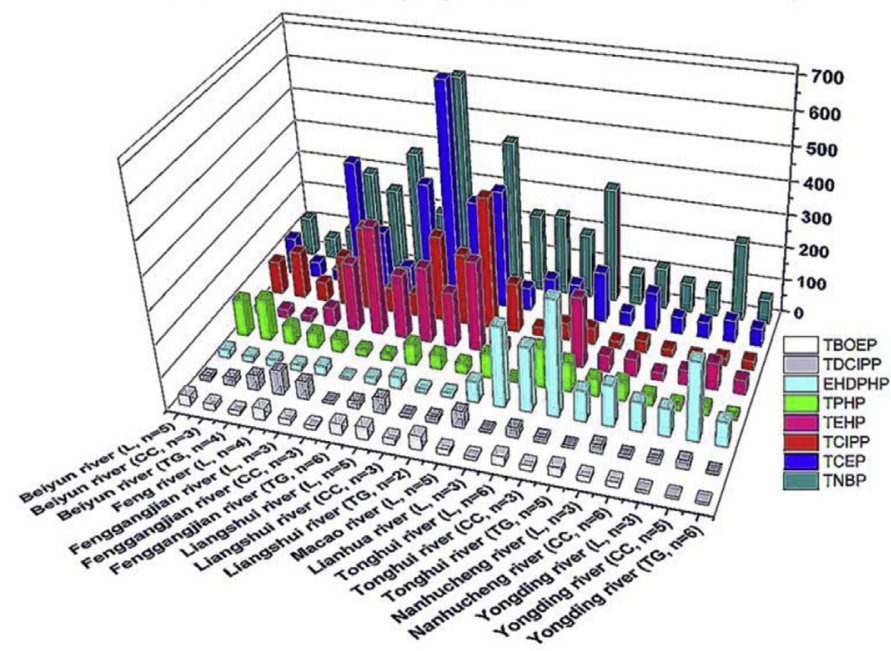

\section{Mean DAPs (ng/g lw) in whole-body}

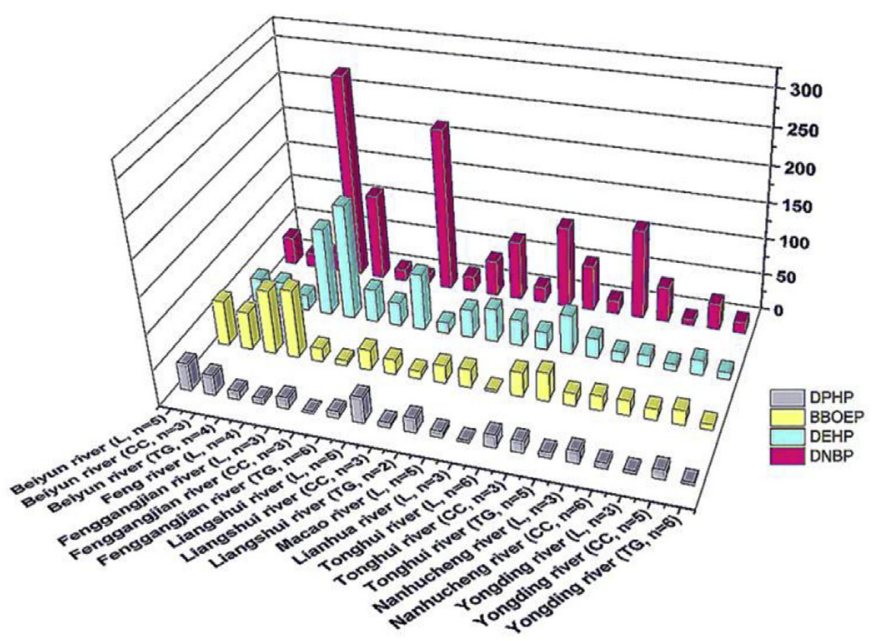

L- Loach

TG- Topmouth gudgeon

CC-Crucian carp

Fig. 2. Mean concentrations of PFRs and DAPs in whole-body fish from Beijing, China. 
Table 1

Summary of $\Sigma$ PFRs and Chlorinated PFRs (sum of TDCIPP, TCIPP and TCEP) concentrations (on ng/g lipid weight) in fish around the world.

\begin{tabular}{|c|c|c|c|c|c|c|c|c|}
\hline \multirow[t]{2}{*}{ Location } & \multirow[t]{2}{*}{ Species } & \multirow{2}{*}{\multicolumn{2}{|c|}{ Year $\mathrm{n}$}} & \multicolumn{2}{|l|}{$\Sigma$ PFRs } & \multicolumn{2}{|c|}{ Chlorinated PFRs } & \multirow[t]{2}{*}{ References } \\
\hline & & & & $\begin{array}{l}\text { Mean } \\
\text { concentration }\end{array}$ & Range & $\begin{array}{l}\text { Mean } \\
\text { concentration }\end{array}$ & Range & \\
\hline Beijing, China & $\begin{array}{l}\text { Topmouth gudgeon, Crucian carp and } \\
\text { Loach }\end{array}$ & 2016 & 83 & 755.18 & $\begin{array}{l}264.69 \\
-1973.17\end{array}$ & 321.99 & $\begin{array}{l}99.93 \\
-976.97\end{array}$ & This study \\
\hline Pearl River Delta, China & Catfish and Grass carp & 2013 & 14 & NA & $\begin{array}{l}353.3 \\
-17,771.2\end{array}$ & NA & $\begin{array}{l}145.4 \\
-5826\end{array}$ & Ma et al. (2013) \\
\hline Western Scheldt Estuary, Netherlands & $\begin{array}{l}\text { Sole, Plaice, Goby, Sculpin, Herring } \\
\text { and } \\
\text { Pouting }\end{array}$ & 2015 & 19 & $37.98^{\mathrm{a}}$ & $9.85-80.8^{\mathrm{a}}$ & $88.22^{\mathrm{a}}$ & ND $-9.8 a$ & $\begin{array}{l}\text { Brandsma et al. } \\
\text { (2015) }\end{array}$ \\
\hline Flanders, Belgium & European eel & 2015 & 170 & 83 & $7.0-330$ & 54.78 & NA & $\begin{array}{l}\text { Malarvannan et al. } \\
\text { (2015) }\end{array}$ \\
\hline Lakes in Canada & Lake Trout and Walleye & 2014 & 72 & $1.56^{\mathrm{a}}$ & $\mathrm{ND}-36.3^{\mathrm{a}}$ & $0.198^{\mathrm{a}}$ & $\mathrm{ND}-1.4^{\mathrm{a}}$ & $\begin{array}{l}\text { McGoldrick et al. } \\
\text { (2014) }\end{array}$ \\
\hline Lakes in Sweden & Herring, Eelpout and Perch & 2010 & 92 & $200^{\mathrm{b}}$ & $61-15,000$ & $153.2^{\mathrm{b}}$ & $12-319$ & $\begin{array}{l}\text { Sundkvist et al. } \\
\text { (2010) }\end{array}$ \\
\hline Costal areas in Sweden & Perch and Carp & 2010 & 29 & $1900^{\mathrm{b}}$ & $\begin{array}{l}1600 \\
-11,000\end{array}$ & $630^{\mathrm{b}}$ & $169-630$ & $\begin{array}{l}\text { Sundkvist et al. } \\
(2010)\end{array}$ \\
\hline Manila Bay, Philippines & $\begin{array}{l}\text { Scad, Mullet, Shad, Mojarra and other } \\
9 \text { families }\end{array}$ & 2011 & 58 & 683.6 & $110-1900$ & NA & NA & Kim et al. (2011) \\
\hline $\begin{array}{l}\text { Barents Sea and west-coast of Spitsbergen, } \\
\text { Norway }\end{array}$ & Atlantic cod and Polar cod & 2009 & 25 & 2498.42 & $\begin{array}{l}169.8 \\
-14,820\end{array}$ & 784.71 & $\begin{array}{l}46.7 \\
-3620\end{array}$ & $\begin{array}{l}\text { Evenset et al. } \\
\text { (2009) }\end{array}$ \\
\hline Costal areas in Norway & Atlantic cod, Trout and Burbot & 2011 & 60 & NA & $9.9-436$ & NA & ND-25.6 & $\begin{array}{l}\text { Leonards et al. } \\
\text { (2011) }\end{array}$ \\
\hline Llobregat river basin, Spain & Barbels, Carps and Trout & 2016 & 12 & NA & ND-2423 & NA & ND-309 & Santín et al. (2016) \\
\hline Evrotas river, Greece & $\begin{array}{l}\text { Menida, Trout, Chub, Barbell, } \\
\text { Grayling and Bullhead }\end{array}$ & 2017 & 4 & 40.1 & $34.1-55.5$ & NA & $\begin{array}{l}3.77 \\
-20.5\end{array}$ & $\begin{array}{l}\text { Giulivo et al. } \\
\text { (2017) }\end{array}$ \\
\hline Adige river, Italy & $\begin{array}{l}\text { Menida, Trout, Chub, Barbell, } \\
\text { Grayling and Bullhead }\end{array}$ & 2017 & 13 & 286 & $50.6-650$ & NA & $0.58-93$ & $\begin{array}{l}\text { Giulivo et al. } \\
\text { (2017) }\end{array}$ \\
\hline $\begin{array}{l}\text { Sava river, Slovenia, Croatia, Bosnia and } \\
\text { Herzegovina and Serbia }\end{array}$ & $\begin{array}{l}\text { Menida, Trout, Chub, Barbell, } \\
\text { Grayling and Bullhead }\end{array}$ & 2017 & 10 & 84 & $14.4-196$ & NA & ND-73.5 & $\begin{array}{l}\text { Giulivo et al. } \\
\text { (2017) }\end{array}$ \\
\hline
\end{tabular}

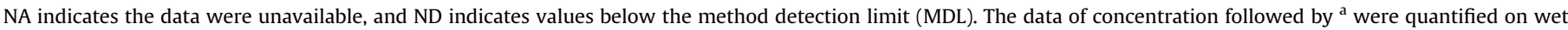
weight; and the concentrations followed by ${ }^{\mathrm{b}}$ were the median concentration.

fish (ng $\cdot \mathrm{g}^{-1}$, on wet weight basis) by the concentrations in water $\left(\mathrm{ng} \cdot \mathrm{ml}^{-1}\right)$. There was no significant difference in the BCFs of the 8 compounds among three selected species $(P=0.81)$. The mean BCFs of TCEP, TCIPP, TDCIPP, TBOEP, TNBP, EHDPHP, TPHP and TEHP in fish from the studied rivers were $34.7,250,27.8,38.5,173,163$, 1008 and 1983, respectively (Fig. S1). TPHP and TEHP were accumulated in the selected fish species the most among the major congeners, based on the REACH criterion (European Union, 2008). The BCF values in the present study were comparable to those reported in killifish, which were 1.1-2.2, 47-113, 35 and 500 for TCEP, TDCIPP, TNBP and TPHP, respectively (Sasaki et al., 1981; WHO, 1998). Correlations between the $\log \mathrm{BCF}$ and $\log K_{\mathrm{OW}}$ values of the target PFRs showed significant but weak relationships in all species $\left(\mathrm{R}^{2}=0.41, P<0.01\right.$, Fig. 3$)$. In addition, to better understand the bioaccumulation of PFRs from sediment, the biota to sediment accumulation factors (BSAFs) were also calculated (comparing the concentrations on lipid weight basis in fish to the concentrations in sediment normalized to organic carbon). The calculated mean BSAFs were displayed in Fig. S1, with no significant difference among species $(P=0.55)$, similar to the BCFs. Most of the PFRs had BSAFs lower than 1 except TEHP (mean BSAF $=1.83$ ), which were consistent with those reported by Giulivo et al. (2017). These results suggested that lipophilicity may not be the only determinant for the accumulation of PFRs, which can also be affected by metabolism and elimination.

\subsubsection{Distribution of PFRs in tissues}

In this study, the tissue distribution of PFRs was examined in the muscle, liver, ovary, intestine and kidney from crucian carp and loach (Fig. 4; Table S6). There were no significant differences in the tissue distribution of PFRs in the two fish species in our study $(P=0.84)$. In crucian carp, the mean $\Sigma$ PFR concentration was the

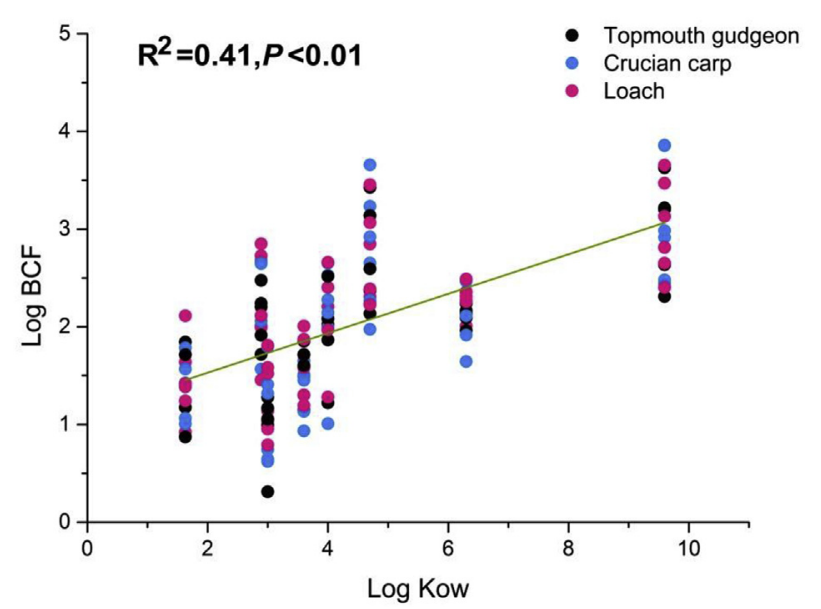

Fig. 3. Correlations between the calculated log BCF and log Kow of the TCEP, TCIPP, TNBP and TPHP.

highest in the liver (576 $\mathrm{ng} \mathrm{g}^{-1} \mathrm{lw}$ ), followed by the kidney (525 $\left.\mathrm{ng} \mathrm{g}^{-1} \mathrm{lw}\right)$, the muscle (451 $\left.\mathrm{ng} \mathrm{g}^{-1} \mathrm{lw}\right)$, the intestine (364 $\mathrm{ng} \mathrm{g}^{-1} \mathrm{lw}$ ) and the ovary ( $251 \mathrm{ng} \mathrm{g}^{-1} \mathrm{lw}$ ). The mean $\Sigma$ PFR concentrations in the tissues of loach followed the order of liver $\left(861 \mathrm{ng} \mathrm{g}^{-1} \mathrm{lw}\right)>$ intestine $\left(529 \mathrm{ng} \mathrm{g}^{-1} \mathrm{lw}\right)>$ kidney (330 $\mathrm{ng} \mathrm{g}^{-1}$ $\mathrm{lw})>$ muscle $\left(329 \mathrm{ng} \mathrm{g}^{-1} \mathrm{lw}\right)>$ ovary $\left(207 \mathrm{ng} \mathrm{g}^{-1} \mathrm{lw}\right)$. In addition, the compositional profiles of PFRs showed no significant differences among tissues in both crucian carp and loach $(P=0.71$ and $P=0.89$, respectively).

In the tissues of fish, the highest $\Sigma$ PFR concentrations were observed in the liver for both species, indicating the higher accumulation of PFRs in metabolically active tissue of fish. In an early 

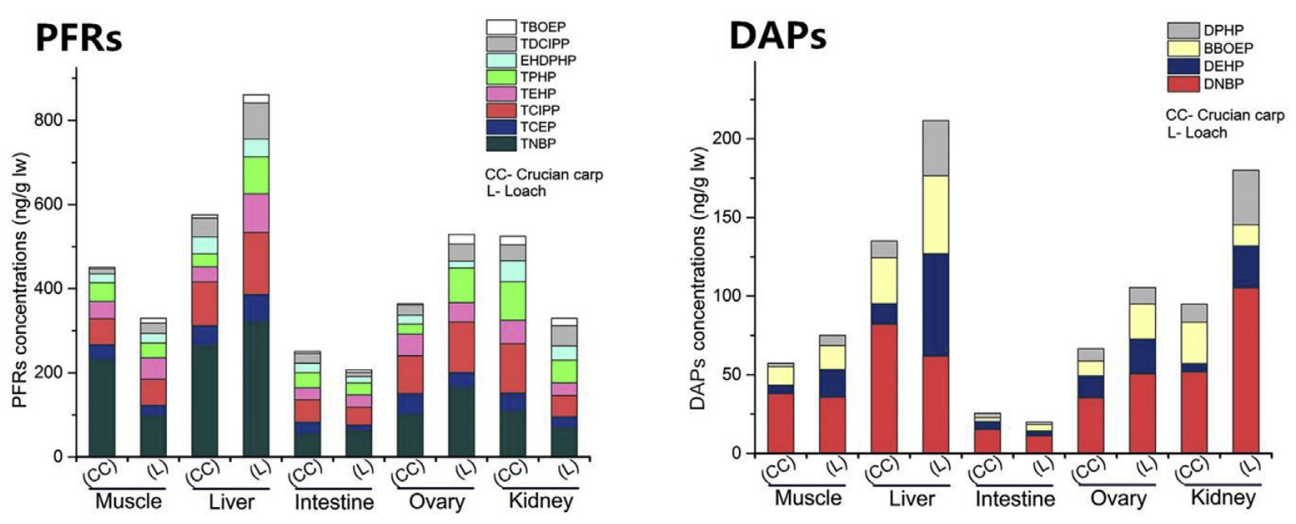

Fig. 4. Tissue distributions of $\Sigma$ PFRs and $\Sigma$ DAPs in two freshwater fish species from Beijing, China.

study, PFR levels in the liver of Atlantic cod were found to be 4.2-46.6 (mean 10.6) times higher than those in whole-body fish samples from Svalbard, Norway (Evenset et al., 2009). Previous reports also indicated higher concentrations of PFRs in the liver and kidney compared with other tissues (testis, adipose, muscle, etc.) in rats after oral administration of these compounds (Lynn et al., 1981; Minegishi et al., 1988). However, in contrast, a recent study found that PFRs moderately accumulated in blubber (as high as $450 \mathrm{ng} \mathrm{g}^{-1}$ wet weight), but nearly no PFRs accumulated in the liver of harbor porpoise from the UK (Papachlimitzou et al., 2015). Greaves and Letcher (2014) demonstrated that PFRs were highly distributed in metabolically inactive tissues such as adipose tissue, muscle and eggs in the Great Lakes herring gull, whereas no PFRs were detected in the liver. These reports demonstrate that differences may exist in the tissue distribution of PFRs across different species. It seems that PFRs are more likely to accumulate in metabolically active tissues (liver or kidney) in fish but in metabolically inactive tissues (muscle, ovary, and adipose) in avian. The differences in tissue distribution between fish and avian have also been reported previously for PBDEs. For example, PBDEs preferentially accumulated in the liver or/and kidneys of freshwater fish in the reports of Kim et al. (2015), Xian et al. (2008) and Zeng et al. (2013), whereas a higher accumulation of PBDEs was found in the muscle and adipose tissues compared with other tissues in birds of prey in Belgium (Voorspoels et al., 2006) and in domestic hens and ducks in China (Yang et al., 2011).

Many factors can influence the levels of PFRs in the tissues of fish. Unlike PBDEs and HBCDs (hexabromocyclododecanes), PFRs are considered to have limited lipid affinity (Brandsma et al., 2015; Chen et al., 2012; Greaves and Letcher, 2014; Kim et al., 2011; Malarvannan et al., 2015; Sundkvist et al., 2010). In our investigation, we did not find a significant correlation between the $\Sigma$ PFRs and the lipid content in various tissues for either species $\left(R^{2}=0.09\right.$ and $P=0.20$ for crucian carp; $R^{2}=0.01$ and $P=0.39$ for loach). Thus, we conclude that passive biotransport may not be the main factor influencing the tissue distribution of PFRs, which is consistent with Greaves and Letcher (2014). It is also possible that active accumulation through the direct interaction of specific biomolecules may be responsible for the distribution of PFRs in the body (Greaves and Letcher, 2014). The preferential accumulation of PFRs in the liver of fish in our study may be related to the liver's detoxifying activities. Huang et al. (2001) and Wu et al. (2009) explained the selective accumulation of xenobiotic contaminants such as PCBs and PBDEs in various frog species by the high affinity of enzyme cytochrome P450 1A. Minegishi et al. (1988) found that tris(2,3-dibromopropyl) phosphate (TDBPP) was active in binding with the S9 protein from rat liver and kidney. On the other hand,
Wu et al. (2009) also indicated that high binding of PBDEs to blood proteins could contribute to their accumulation in blood-rich organs such as the liver and kidneys. We can assume that the same hypothesis can also be used for the distribution of PFRs in the body. Moreover, PFRs can be rapidly metabolized in the liver before being transported to other tissues (Hou et al., 2016), thus making these compounds less accumulated in the muscle and ovaries of fish in our study. Since the tissue distribution of PFRs in aquatic animals is not well understood, more comprehensive studies on the mechanism and kinetics of the tissue-specific accumulation of PFRs in the body are still required.

\subsection{Levels and tissue distribution of DAPs in fish}

\subsubsection{Whole-body concentrations of DAPs}

In the present study, we also investigated DAPs in whole-fish homogenates from rivers in Beijing (Fig. 2). The 4 DAPs were detected in nearly all samples, with detection frequencies of $>91 \%$ for all compounds. The mean concentration of $\Sigma$ DAPs (sum of BBOEP, DPHP, DNBP and DEHP) was $153 \mathrm{ng} \mathrm{g}^{-1} \mathrm{lw}$, from values ranging from 35.3 to $510 \mathrm{ng} \mathrm{g}^{-1} \mathrm{lw}$. The distribution of total DAPs across the bodies of water in this study were consistent with the distribution of total PFRs. The mean $\Sigma$ DAPs were observed to be relatively large in fish from Feng river $\left(510 \mathrm{ng} \mathrm{g}^{-1} \mathrm{lw}\right)$, Liang-shui river (183 $\mathrm{ng} \mathrm{g}^{-1} \mathrm{lw}$ ) and Feng-gang-jian river (156 $\mathrm{ng} \mathrm{g}^{-1} \mathrm{lw}$ ). Meanwhile, the lowest mean $\Sigma$ DAPs was observed in fish collected from Yong-ding river $\left(53.1 \mathrm{ng} \mathrm{g}^{-1} \mathrm{lw}\right)$. With respect to the distribution in different species, there were higher but non-significant $\Sigma$ DAPs levels in loach than in topmouth gudgeon and crucian carp from all bodies of water $(P=0.21)$. The lack of obvious trend for PFRs may be because there was a relatively more efficient absorption of DAPs or/and limited metabolism of PFRs in loach than in other species. This is the first investigation of DAPs in wild fish to our knowledge.

For the compositional profiles of DAPs, the mean concentration of DNBP (64.5 $\mathrm{ng} \mathrm{g}^{-1} \mathrm{lw}$ ) reported in fish from all bodies of water was significantly greater than the mean concentrations of DEHP, BBOEP and DPHP (41.2, 30.3 and $14.1 \mathrm{ng} \mathrm{g}^{-1} \mathrm{lw}$, respectively) in fish from all bodies of water $(\mathrm{P}<0.05$; Table S5). DNBP accounted for $12.8-70.8 \%$ of the $\Sigma$ DAP concentration, with an average of $42.1 \%$. As the metabolite of TNBP, the dominance of DNBP was consistent with the abundance of its parent compound found in the fish in the present study. BBOEP was also detected at relatively high levels, even though the TBOEP concentration was the lowest of the PFR congeners in whole-body fish samples. This may indicate that a larger proportion of TBOEP was metabolized in fish compared with the other PFRs. 


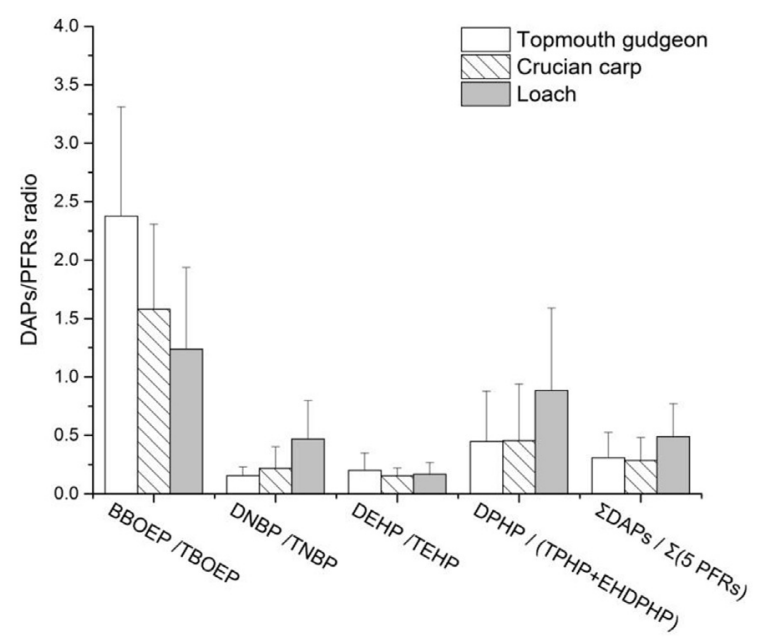

Fig. 5. The mean concentration ratio of DAPs and their corresponding PFRs in wholebody fish from Beijing, China.

The metabolite/parent ratio (MPR) can provide a convenient way to characterize the bioaccumulation potential of the metabolite, and a ratio $>1$ indicates that the metabolites may be of greater concern with respect to their accumulation potential in biota (Kuo and Chen, 2016). We calculated MPRs for the 4 independent DAP/ PFR pairs detected in whole-body fish samples of all species, as well as the MPRs of total DAPs ( $\Sigma$ DAPs) to the sum of their 5 parent compounds (TBOEP, TEHP, TNBP, TPHP and EHDPHP), as shown in Fig. 5. Because DPHP can be metabolized from both TPHP and EHDPHP (Ballesteros-Gómez et al., 2015a), the sum of the TPHP and EHDPHP concentrations was used as the parent concentration in the estimation of the metabolite/parent ratio for this pair. There was no significant difference in the MPRs of both the independent and the total DAP/PFR pairs among species $(P=0.38)$. Only the BBOEP/TBOEP pair showed a high MPR (ranging from 0.58 to 2.64, mean value of 1.61), while the MPRs for all other independent pairs were less than 1 , with mean values of $0.30,0.17$ and 0.63 for DNBP/ TNBP, DEHP/TEHP and DPHP/(TPHP+EHDPHP), respectively. The ratio of $\Sigma$ DAPs $/ \Sigma$ (5PFRs) ranged from 0.10 to 1.12 (mean value of 0.38 ) in the whole-body fish samples. It is very likely that these DAPs are far less hydrophobic, are quickly cleared from the body as phosphoric acids, and are slightly less bioaccumulated in fish than their parent compounds. Even so, the DAP levels in fish being of the same order of magnitude as their parent compounds suggests the importance of monitoring DAPs in animals to evaluate the internal exposure of PFRs.

\subsubsection{Distribution of DAPs in tissues}

Similar to PFRs, all 4 DAPs were consistently found in the tissues of crucian carp and loach (Table S6). DNBP was found to be the predominant isomer in all fish tissues. As illustrated in Fig. 4, no significant differences in the distribution of the $\mathrm{DDAPs}$ in tissues were observed between the two species $(P=0.69)$, showing the same order of liver $>$ kidney $>$ intestine $>$ muscle $>$ ovary. The maximum $\Sigma$ DAPs for crucian carp and loach were found in the liver at mean levels of 135 and $212 \mathrm{ng} \mathrm{g}^{-1} \mathrm{lw}$, respectively, followed by the kidney at mean levels of 94.9 and $180 \mathrm{ng} \mathrm{g}^{-1} \mathrm{lw}$, respectively. The lowest levels were generally found in the ovary of crucian carp and loach (mean 25.6 and $19.9 \mathrm{ng} / \mathrm{g}$ lw, respectively). The relatively higher loading of DAPs in the liver and kidney may be due to their important detoxifying function in the body. Because no positive correlation between the level of $\Sigma$ DAPs and lipid content in tissues $\left(\mathrm{R}^{2}=0.07\right.$ and $P=0.39$ for crucian carp; $\mathrm{R}^{2}=0.05$ and $P=0.60$ for loach) was found, it is also suggested that hydrophobicity does not play a major role in the distribution of DAPs among tissues, similar to the situation with PFRs.

The MPRs for the 4 independent DAP/PFR pairs and $\Sigma$ DAPs/ $\Sigma$ (5PFRs) were evaluated in various tissues of fish (Fig. 6). The MPRs for all 5 pairs were the highest in the kidney relative to the other tissues but not significant in both crucian carp and loach $(P=0.21$ for crucian carp; $P=0.06$ for loach). This could be a result of the key role of the kidney in eliminating PFR metabolites. Previous studies have suggested that DAPs in human urine are important biomarkers of PFR exposure (Alves et al., 2014; Cooper et al., 2011; Dodson et al., 2014; Meeker et al., 2013b), further indicating the significance of excreting DAPs from the body through the kidney.

\section{Conclusion}

The present study examined the distribution of PFRs and DAPs in whole-body samples and various tissue samples of freshwater fish. Relatively high PFR accumulation was found in freshwater fish from our survey area. Importantly, our study showed for the first time that the accumulation of DAPs was relatively lower but comparable to that of PFRs in freshwater fish. Similar to their parent
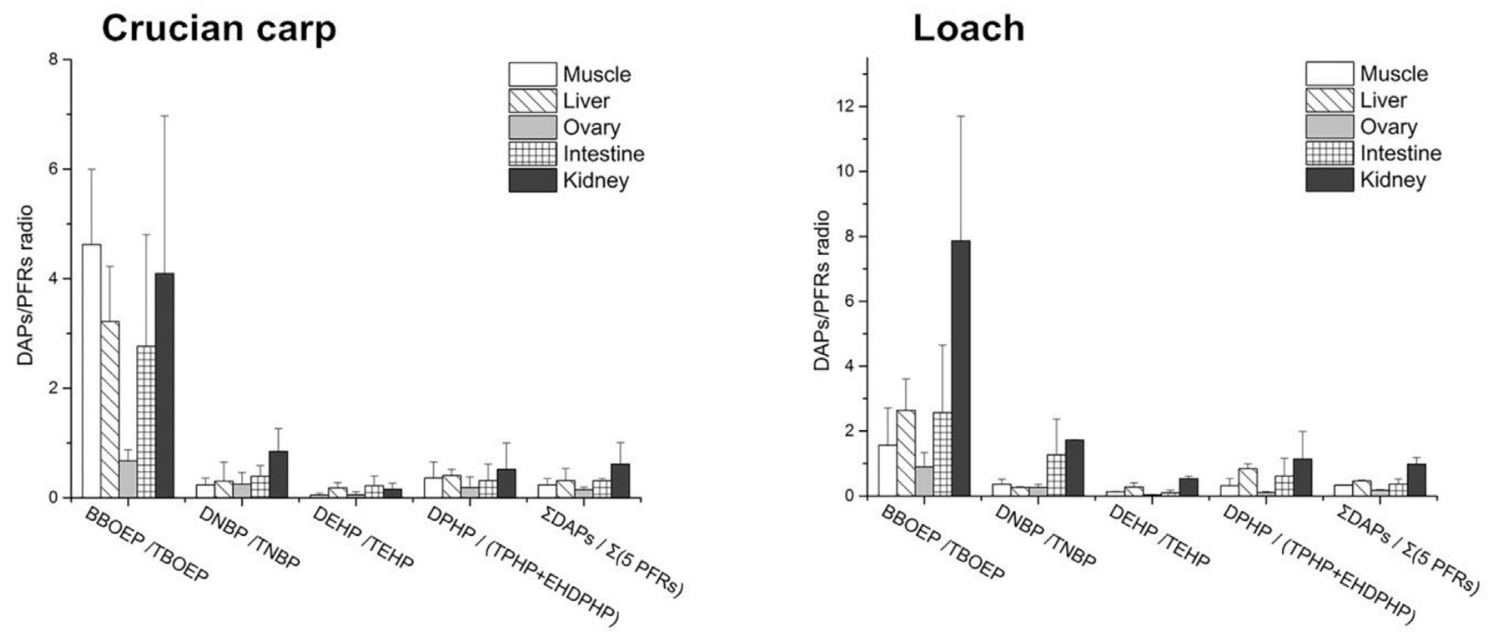

Fig. 6. The mean concentration ratio of DAPs and their corresponding PFRs in various tissues of fish. 
PFRs, DAP concentrations had limited correlation with the lipid content in the tissues, suggesting the exposure indicator role of DAPs in wild animal studies, which was recently underlined by the recommendation to investigate of PFR metabolites to reflect the actual PFR contamination (Greaves and Letcher, 2014; Malarvannan et al., 2015; McGoldrick et al., 2014).

This study also improved our understanding of the distribution of PFRs and DAPs in the tissues of fish. The liver was found to have a higher accumulation of PFRs and DAPs than the other tissues of fish. However, it should be considered that this study is based on a single investigation; a systematic toxicokinetics study including the ADME (absorption, distribution, metabolism and excretion) processes of PFRs in the body is warranted. Furthermore, identification of internal exposure biomarkers of PFRs (such as DAPs and other metabolites) in fish should also be taken into account to further elucidate the ecological risk of PFRs.

\section{Data availability}

Data, associated metadata, and calculation tools are available by contacting the corresponding author (ypxu@rcees.ac.cn).

\section{Acknowledgement}

This work is supported by the National Natural Science Foundation of China (No. 41571469, No. 21437006) and Science and Technology Service Network Initiative of Chinese Academy of Sciences (KFJ-SW-STS-171).

\section{Appendix A. Supplementary data}

Supplementary data related to this article can be found at http:// dx.doi.org/10.1016/j.envpol.2017.06.097.

\section{References}

Alves, A., Kucharska, A., Erratico, C., Xu, F., Den Hond, E., Koppen, G., Vanermen, G. Covaci, A., Voorspoels, S., 2014. Human biomonitoring of emerging pollutants through non-invasive matrices: state of the art and future potential. Anal. Bioanal. Chem. 406, 4063-4088.

Andresen, J.A., Grundmann, A., Bester, K., 2004. Organophosphorus flame retardants and plasticisers in surface waters. Sci. Total Environ. 332, 155-166.

Ballesteros-Gómez, A., Erratico, C.A., Eede, N.V.d., Ionas, A.C., Leonards, P.E.G. Covaci, A., 2015a. In vitro metabolism of 2-ethylhexyldiphenyl phosphate (EHDPHP) by human liver microsomes. Toxicol. Lett. 232, 203-212.

Ballesteros-Gómez, A., Van den Eede, N., Covaci, A., 2015b. In vitro human metabolism of the flame retardant resorcinol bis(diphenylphosphate) (RDP). Environ. Sci. Technol. 49, 3897-3904.

Bergman, Å., Rydén, A., Law, R.J., de Boer, J., Covaci, A., Alaee, M., Birnbaum, L. Petreas, M., Rose, M., Sakai, S., Van den Eede, N., van der Veen, I., 2012. A nove abbreviation standard for organobromine, organochlorine and organophosphorus flame retardants and some characteristics of the chemicals. Environ. Int. 49, 57-82.

Brandsma, S.H., Leonards, P.E.G., Leslie, H.A., de Boer, J., 2015. Tracing organophosphorus and brominated flame retardants and plasticizers in an estuarine food web. Sci. Total Environ. 505, 22-31.

Butt, C.M., Congleton, J., Hoffman, K., Fang, M., Stapleton, H.M., 2014. Metabolites of organophosphate flame retardants and 2-ethylhexyl tetrabromobenzoate in urine from paired mothers and toddlers. Environ. Sci. Technol. 48, $10432-10438$

Cao, S., Zeng, X., Song, H., Li, H., Yu, Z., Sheng, G., Fu, J., 2012. Levels and distributions of organophosphate flame retardants and plasticizers in sediment from Taihu Lake, China. Environ. Toxicol. Chem. 31, 1478-1484.

Cequier, E., Ionas, A.C., Covaci, A., Marcé, R.M., Becher, G., Thomsen, C., 2014 Occurrence of a broad range of legacy and emerging flame retardants in indoor environments in Norway. Environ. Sci. Technol. 48, 6827-6835.

Cequier, E., Marcé, R.M., Becher, G., Thomsen, C., 2014b. A high-throughput method for determination of metabolites of organophosphate flame retardants in urine by ultra performance liquid chromatography-high resolution mass spectrometry. Anal. Chim. Acta 845, 98-104.

Cequier, E., Sakhi, A.K., Marcé, R.M., Becher, G., Thomsen, C., 2015. Human exposure pathways to organophosphate triesters - a biomonitoring study of mother-child pairs. Environ. Int. 75, 159-165.

Chen, D., Letcher, R.J., Chu, S., 2012. Determination of non-halogenated, chlorinated and brominated organophosphate flame retardants in herring gull eggs based on liquid chromatography-tandem quadrupole mass spectrometry. J. Chromatogr. A 1220, 169-174.

Chu, S., Chen, D., Letcher, R.J., 2011. Dicationic ion-pairing of phosphoric acid diesters post-liquid chromatography and subsequent determination by electrospray positive ionization-tandem mass spectrometry. J. Chromatogr. A 1218, 8083-8088.

Chung, H.W., Ding, W.H., 2009. Determination of organophosphate flame retardants in sediments by microwave-assisted extraction and gas chromatography-mass spectrometry with electron impact and chemical ionization. Anal. Bioanal. Chem. 395, 2325-2334.

Cooper, E.M., Covaci, A., Van Nuijs, A.L.N., Webster, T.F., Stapleton, H.M., 2011. Analysis of the flame retardant metabolites bis(1,3-dichloro-2-propyl) phosphate (BDCPP) and diphenyl phosphate (DPP) in urine using liquid chromatography-tandem mass spectrometry. Anal. Bioanal. Chem. 401, 2123-2132.

Cristale, J., Katsoyiannis, A., Sweetman, A.J., Jones, K.C., Lacorte, S., 2013. Occurrence and risk assessment of organophosphorus and brominated flame retardants in the River Aire (UK). Environ. Pollut. 179, 194-200.

Dodson, R.E., Van den Eede, N., Covaci, A, Perovich, LJ., Brody, J.G. Rudel, R.A. 2014. Urinary biomonitoring of phosphate flame retardants: levels in California adults and recommendations for future studies. Environ. Sci. Technol. 48, 13625-13633.

European Union, 2008. European Union Risk Assessment Report: Tris (1-chloro-2propyl) Phosphate (TCPP), EINECS No: 237-158-7. Office for Official Publications of the European Communities, Luxembourg, pp. 2019-2051.

Evenset, A., Leknes, H., Christensen, G.N., Warner, N., Remberger, M. Gabrielsen, G.W., 2009. Screening of New Contaminants in Samples from the Norwegian Arctic Rapport, Akvaplan-niva Report. Norwegian Pollution Control Agency, Norway.

Giulivo, M., Capri, E., Kalogianni, E., Milacic, R., Majone, B., Ferrari, F., Eljarrat, E., Barceló, D., 2017. Occurrence of halogenated and organophosphate flame retardants in sediment and fish samples from three European river basins. Sci. Total Environ. 586, 782-791.

Greaves, A.K., Letcher, R.J., 2014. Comparative body compartment composition and in ovo transfer of organophosphate flame retardants in North American Great lakes herring gulls. Environ. Sci. Technol. 48, 7942-7950.

Hou, R., Xu, Y., Wang, Z., 2016. Review of OPFRs in animals and humans: absorption, bioaccumulation, metabolism, and internal exposure research. Chemosphere 153, 78-90.

Hu, M., Li, J., Zhang, B., Cui, O., Wei, S., Yu, H., 2014. Regional distribution of halogenated organophosphate flame retardants in seawater samples from three coastal cities in China. Mar. Pollut. Bull. 86, 569-574.

Huang, Y.W., Stegeman, J.J., Woodin, B.R., Karasov, W.H., 2001. Immunohistochemical localization of cytochrome P4501A induced by $3,3^{\prime}, 4,4^{\prime}, 5^{-}$ pentachlorobiphenyl (PCB 126) in multiple organs of northern leopard frogs, Rana pipiens. Environ. Toxicol. Chem. 20, 191-197.

Jing, H.W. Zhang, Z.G., Guo, J., 2013. Water pollution characteristics and pollution sources of Bei Canal river system in Beijing. China Environ. Sci. 33, 319-327 (in Chinese).

Kang, B., Deng, J., Wu, Y., Chen, L., Zhang, J., Qiu, H., Lu, Y., He, D., 2014. Mapping China's freshwater fishes: diversity and biogeography. Fish Fish. 15, 209-230.

Kim, J.W., Isobe, T., Chang, K.H., Amano, A., Maneja, R.H., Zamora, P.B., Siringan, F.P., Tanabe, S., 2011. Levels and distribution of organophosphorus flame retardants and plasticizers in fishes from Manila Bay, the Philippines. Environ. Pollut. 159, $3653-3659$

Kim, U.J., Jo, H., Lee, I.S., Joo, G.J., Oh, J.E., 2015. Investigation of bioaccumulation and biotransformation of polybrominated diphenyl ethers, hydroxylated and methoxylated derivatives in varying trophic level freshwater fishes. Chemosphere 137, 108-114.

Kuo, D.T.F., Chen, C.C., 2016. Deriving in vivo biotransformation rate constants and metabolite parent concentration factor/stable metabolite factor from bioaccumulation and bioconcentration experiments: an illustration with worm accumulation data. Environ. Toxicol. Chem. 35, 2903-2909.

Lai, S., Xie, Z. Song, T., Tang, J., Zhang, Y. Mi, W., Peng, J., Zhao, Y., Zou, S. Ebinghaus, R., 2015. Occurrence and dry deposition of organophosphate esters in atmospheric particles over the northern South China Sea. Chemosphere 127, 195-200.

Leonards, P., Steindal, E.H., Van der Veen, I., Berg, V., Bustnes, J.O., Van Leeuwen, S., 2011. Screening of Organophosphor Flame Retardants 2010. Norwegian Climate and Pollution Agency, Norway.

Lynn, R.K., Wong, K., Garvie-Gould, C., Kennish, J.M., 1981. Disposition of the flame retardant, tris(1,3-dichloro-2-propyl) phosphate, in the rat. Drug Metabol Dispos. 9, 434-441.

Ma, Y., Cui, K., Zeng, F., Wen, J., Liu, H., Zhu, F., Ouyang, G., Luan, T., Zeng, Z., 2013. Microwave-assisted extraction combined with gel permeation chromatography and silica gel cleanup followed by gas chromatography-mass spectrometry for the determination of organophosphorus flame retardants and plasticizers in biological samples. Anal. Chim. Acta 786, 47-53.

Malarvannan, G., Belpaire, C., Geeraerts, C., Eulaers, I., Neels, H., Covaci, A., 2015. Organophosphorus flame retardants in the European eel in Flanders, Belgium: occurrence, fate and human health risk. Environ. Res. 140, 604-610.

McGoldrick, D.J., Letcher, R.J., Barresi, E., Keir, M.J., Small, J., Clark, M.G., Sverko, E., Backus, S.M., 2014. Organophosphate flame retardants and organosiloxanes in predatory freshwater fish from locations across Canada. Environ. Pollut. 193, 
$254-261$

Meeker, J.D., Cooper, E.M., Stapleton, H.M., Hauser, R., 2013a. Exploratory analysis of urinary metabolites of phosphorus-containing flame retardants in relation to markers of male reproductive health. Endocr. Disrupt. 1, e26306.

Meeker, J.D., Cooper, E.M., Stapleton, H.M., Hauser, R., 2013b. Urinary metabolites of organophosphate flame retardants: temporal variability and correlations with house dust concentrations. Environ. Health Perspect. 121, 580-585.

Mihajlović, I., Miloradov, M.V., Fries, E., 2011. Application of twisselmann extraction, SPME, and GC-MS to assess input sources for organophosphate esters into soil. Environ. Sci. Technol. 45, 2264-2269.

Minegishi, K., Kurebayashi, H., Nambaru, S., Morimoto, K., Takahashi, T., Yamaha, T., 1988. Comparative studies on absorption, distribution, and excretion of flame retardants halogenated alkyl phosphate in rats. Eisei kagaku 34, 102-114.

Nomeir, A.A., Kato, S., Matthews, H.B., 1981. The metabolism and disposition of tris(1,3-dichloro-2-propyl) phosphate (fyrol FR-2) in the rat. Toxicol. Appl. Pharmacol. 57, 401-413.

Papachlimitzou, A., Barber, J.L., Losada, S., Bersuder, P., Deaville, R., Brownlow, A., Penrose, R., Jepson, P.D., Law, R.J., 2015. Organophosphorus flame retardants (PFRs) and plasticisers in harbour porpoises (Phocoena phocoena) stranded or bycaught in the UK during 2012. Mar. Pollut. Bull. 98, 328-334.

Preston, E.V., McClean, M.D., Claus Henn, B., Stapleton, H.M., Braverman, L.E., Pearce, E.N., Makey, C.M., Webster, T.F., 2017. Associations between urinary diphenyl phosphate and thyroid function. Environ. Int. 101, 158-164.

Reemtsma, T., Lingott, J., Roegler, S., 2011. Determination of 14 monoalkyl phosphates, dialkyl phosphates and dialkyl thiophosphates by LC-MS/MS in human urinary samples. Sci. Total Environ. 409, 1990-1993.

Santín, G., Eljarrat, E., Barceló, D., 2016. Simultaneous determination of 16 organophosphorus flame retardants and plasticizers in fish by liquid chromatography-tandem mass spectrometry. J. Chromatogr. A 1441, 34-43.

Sasaki, K., Suzuki, T., Takeda, M., Uchiyama, M., 1984. Metabolism of phosphoric acid triesters by rat liver homogenate. Bull. Environ. Contam. Toxicol. 33, 281-288.

Sasaki, K., Takeda, M., Uchiyama, M., 1981. Toxicity, absorption and elimination of phosphoric acid triesters by killifish and goldfish. Bull. Environ. Contam. Toxicol. 27, 775-782.

Shoeib, M., Ahrens, L., Jantunen, L., Harner, T., 2014. Concentrations in air of organobromine, organochlorine and organophosphate flame retardants in Toronto, Canada. Atmos. Environ. 99, 140-147.

Staaf, T., Ostman, C., 2005. Organophosphate triesters in indoor environments. J. Environ. Monit. 7, 883-887.

State of Washington, 2016. Certification of enrollment - engrossed substitute house bill 2545. Available from:http://lawfilesext.leg.wa.gov/biennium/2011-12/Pdf/ Bills/House\%20Passed\%20Legislature/2545-S.PL.pdf?mqcreq=1. .

Su, G., Greaves, A.K., Gauthier, L., Letcher, R.J., 2014. Liquid chromatography-electrospray-tandem mass spectrometry method for determination of organophosphate diesters in biotic samples including Great Lakes herring gull plasma. J. Chromatogr. A 1374, 85-92.

Su, G., Letcher, R.J., Crump, D., Gooden, D.M., Stapleton, H.M., 2015. In vitro metabolism of the flame retardant triphenyl phosphate in chicken embryonic hepatocytes and the importance of the hydroxylation pathway. Environ. Sci. Technol. Lett. 2, 100-104.

Sundkvist, A.M., Olofsson, U., Haglund, P., 2010. Organophosphorus flame retardants and plasticizers in marine and fresh water biota and in human milk. J. Environ. Monit. 12, 943-951.

Suzuki, T., Sasaki, K., Takeda, M., Uchiyama, M., 1984. Metabolism of tributyl phosphate in male rats. J. Agric. Food Chem. 32, 603-610.
Tan, X.X., Luo, X.J., Zheng, X.B., Li, Z.R., Sun, R.X., Mai, B.X., 2016. Distribution of organophosphorus flame retardants in sediments from the Pearl River Delta in south China. Sci. Total Environ. 544, 77-84.

The District of Columbia, 2016. Carcinogenic flame retardant prohibition amendment act of 2016. Available from: http://159.226.240.76/lims.dccouncil.us Download/33567/B21-0143-SignedAct.pdf.

Van den Eede, N., Erratico, C., Exarchou, V., Maho, W., Neels, H., Covaci, A., 2015a. In vitro biotransformation of tris(2-butoxyethyl) phosphate (TBOEP) in human liver and serum. Toxicol. Appl. Pharmacol. 284, 246-253.

Van den Eede, N., Heffernan, A.L., Aylward, L.L., Hobson, P., Neels, H., Mueller, J.F., Covaci, A., 2015b. Age as a determinant of phosphate flame retardant exposure of the Australian population and identification of novel urinary PFR metabolites. Environ. Int. 74, 1-8.

Van den Eede, N., Maho, W., Erratico, C., Neels, H., Covaci, A., 2013a. First insights in the metabolism of phosphate flame retardants and plasticizers using human liver fractions. Toxicol. Lett. 223, 9-15.

Van den Eede, N., Neels, H., Jorens, P.G., Covaci, A., 2013b. Analysis of organophosphate flame retardant diester metabolites in human urine by liquid chromatography electrospray ionisation tandem mass spectrometry. J. Chromatogr. A 1303, 48-53.

Van der Veen, I., de Boer, J., 2012. Phosphorus flame retardants: properties, production, environmental occurrence, toxicity and analysis. Chemosphere 88 $1119-1153$.

Voorspoels, S., Covaci, A., Lepom, P., Jaspers, V.L.B., Schepens, P., 2006. Levels and distribution of polybrominated diphenyl ethers in various tissues of birds of prey. Environ. Pollut. 144, 218-227.

Wang, R., Tang, J., Xie, Z., Mi, W., Chen, Y., Wolschke, H., Tian, C., Pan, X., Luo, Y, Ebinghaus, R., 2015. Occurrence and spatial distribution of organophosphate ester flame retardants and plasticizers in 40 rivers draining into the Bohai Sea north China. Environ. Pollut. 198, 172-178.

Wei, G.L., Li, D.Q., Zhuo, M.N., Liao, Y.S., Xie, Z.Y., Guo, T.L., Li, J.J., Zhang, S.Y. Liang, Z.Q., 2015. Organophosphorus flame retardants and plasticizers: sources, occurrence, toxicity and human exposure. Environ. Pollut. 196, 29-46.

WHO, 1998. Flame Retardants: Tris(Chloropropyl) Phosphate and Tris(2chloropropyl) Phosphate. Environmental Health Criteria 209. World Health Organization, Geneva, Switzerland.

WHO, 2000. Flame Retardants: Tris(2-butoxyethyl) Phosphate, Tris(2-ethylhexyl) Phosphate and Tetrakis(hydroxymethyl) Phosphonium Salts. Environmental Health Criteria 218. World Health Organization, Geneva, Switzerland.

Wu, J.P., Luo, X.J., Zhang, Y., Chen, S.J., Mai, B.X., Guan, Y.T., Yang, Z.Y., 2009. Residues of polybrominated diphenyl ethers in frogs (Rana limnocharis) from a contaminated site, South China: tissue distribution, biomagnification, and maternal transfer. Environ. Sci. Technol. 43, 5212-5217.

Xian, Q, Ramu, K., Isobe, T, Sudaryanto, A., Liu, X., Gao, Z, Takahashi, S., Yu, H. Tanabe, S., 2008. Levels and body distribution of polybrominated diphenyl ethers (PBDEs) and hexabromocyclododecanes (HBCDs) in freshwater fishes from the Yangtze River, China. Chemosphere 71, 268-276.

Yang, Z.Z., Li, Y.F., Fu, S., Zhao, X.R., 2011. Special distribution of polybrominated diphenyl ethers in brain tissues of free-range domestic hens and ducks from a village near an electronic waste recycling site in South China. Bull. Environ. Contam. Toxicol. 86, 283-288.

Zeng, Y.H., Yu, L.H., Luo, X.J., Chen, S.J., Wu, J.P., Mai, B.X., 2013. Tissue accumulation and species-specific metabolism of technical pentabrominated diphenyl ether (DE-71) in two predator fish. Environ. Toxicol. Chem. 32, 757-763. 